\title{
The Effect of Communication Strategies on Learners' Speaking Ability in Task- Based Language Teaching: A Mixed Methods Analysis
}

\section{Yoshiko Kozawa}

\section{Suzuka University of Medical Science}

This study examines the diversity of applications of instructed prefabricated patterns of communication strategies (PPCS) by novice learners of English, the influence on speaking competence of frequent PPCS use by learners, and correlations between PPCS use and learners' development in speaking. Their perceptions about the conversation were also surveyed for this purpose. Twenty-four non-English major college students studied English in a semester long course applying TaskBased Language Teaching using PPCS learning. The results showed a propensity toward PPCS with simpler and broader applications. They used PPCS unintentionally while practicing as the class progressed. There was, for example, a significant correlation between the evaluations of learners' conversation by the teachers and the frequent uses of a previously learned "That's..." rejoinder. Learners' positive perceptions about the conversation had significant correlations with some PPCS utilizations. The number of participants and the length of the course yielded limited data and further investigations will clarify these correlations.

本論は、コミュニケーション・ストラテジーの様々な定型表現 (PPCS) が英語の初心者に指導された場合、PPCSの会話への応用の多様性、学 習者がPPCSを頻繁に利用した場合のスピーキングカへの影響、および PPCS使用と学習者のスピーキングカの発達の相関関係を調査する。学 習者の会話に対する認識も調査した。英語専攻ではない24名の短期大 学生が、PPCS学習を含むタスク中心の言語指導のコースで半年間、英語 を学習した。その結果、学生はより簡単に使用できるPPCSをより広く使 う傾向があり、授業でのPPCS練習を積み重ねるにつれ無意識に自然に PPCSが使えるようになつた。教員による会話の評価とそれまでに学んだ “That's …" の短い返答の頻繁な使用には有意な相関が見られ、会話につ いての学習者の肯定的な認識と幾種かのPPCS使用にも有意な相関があ つた。本研究は参加学生数が少なく調査期間も短かったため、さらに調 査を進めることが今後の課題であろう。

\section{Communicative Competence: One Purpose for English Teaching}

One of the main purposes for teaching English is to improve communicative competence (CC) which is defined by Savignon (1972) as "the ability to function in a truly communicative setting" (p. 8). CC consists of grammatical competence, sociocultural competence, discourse competence, and strategic competence according to Canale and Swain (1980). Canale (1983) adds that strategic competence "is composed of mastery of verbal and non-verbal communication strategies" (p. 10). The idea of improving CC inspired me to use communication strategies (CSs). However, CS instruction is somewhat controversial, not because researchers are suspicious about its usefulness, but because the effectiveness of CS instruction has not yet been verified. Some researchers advocate CS instruction (Dörnyei 1995; Færch \& Kasper, 1983a; Tarone, 1984), though others believe CSs are transferred to L2 from the native language and it is therefore not necessary to teach them (Kellerman, 1991). Recent studies have clarified the effect of meta-cognitive CS instruction for oral communication without denying CS transfer from L1 (Nakatani, 2005, 2010; Nakatani \& Goh, 2007). While language transfer of CSs from learners' L1 may occur for some CSs and for some learners, my novice students seem to appreciate and even depend on some of them.

Thus, the development of meaningful instruction of communication strategies would be beneficial for improving CC. In the next section, notable definitions of CS are first introduced then examples and classifications of CS are reviewed.

\section{Communication Strategies: A Helpful Device}

Definitions: CSs are used to facilitate smoother communication by compensating for difficulties caused by a second language user's insufficient competence (Canale \& Swain, 1980; Cohen, 1990; Nakatani, 2005) and some researchers add systematicness or consciousness to CS's definition (Corder, 1981; Færch \& Kasper, 1983b; Tarone 1983). Although they recognize CS importance in native language communication, verbalizing problems of linguistically sufficient speakers does not seem to 
be included in the researchers' definitions. Moreover the purpose of this research is to investigate qualities relevant to the potential improvement of non-native learners' skills. Therefore, the definition of CS here is presupposing L2 learners' communication deficiency.

Classifications of CSs: Many researchers dichotomize CSs into a reduction strategy, including avoidance, and achievement strategy with some compensation (Brown, 2007; Corder, 1981; Færch \& Kasper, 1983a). Some researchers involve paralinguistic strategies in achievement strategies (Bialystok, 1990; Cohen, 1990; Nakatani \& Goh, 2007). Among the various nomenclature for subordinate categories of CSs by Brown (2007) are prefabricated patterns in achievement strategy. This designation would represent useful expressions utilized as achievement strategies and it would be practical for language learners to learn strategic prefabricated patterns for communication. In particular, novice learners, who experience difficulty in constructing sentences, can appreciate prefabricated meaningful expressions they can say as a whole unit. In a sense, by learning prefabricated patterns of communication strategies (PPCSs), learners can, so to speak, kill two birds-learning new expressions and strategies-with one PPCS stone.

The intention of the course investigated here is for students to learn and apply PPCSs in Task-Based Language Teaching (TBLT) conversational tasks. A broad outline of TBLT and its practice in this non-English major course are explained in the next section.

\section{Task-Based Language Teaching}

Communicative language teaching (CLT) using the target language seems reasonable when the primary purpose of language learning is to communicate in the target language. CLT "places a premium on learning through communicating" (Ellis 2008, p. 698). CLT involves both knowledge of language "structures and forms" and "functions and purposes" in different communicative settings and emphasizes "the communication of meaning in interaction rather than the practice and manipulation of grammatical forms in isolation" (Lightbown \& Spada, 2006, p. 196). In CLT classes, teachers prepare different communicative settings, which are called tasks in TBLT. This is a hyponym of CLT according to Brown (2007) and so TBLT was used with the learners in this study.

\section{Research Questions}

The effects of PPCSs on learners' Communicative Competence need to be clarified with regard to the kinds of PPCSs utilized. For that purpose, the following research questions are presented:

1. What PPCSs do low-proficiency Japanese college students use in prompted TBLT activities after PPCS instruction?

2. How do PPCS utilizations correlate with learners' communication?

3. What correlates with PPCS utilizations in novice learners?

\section{Methodology \\ Teaching Implementation}

TBLT was implemented based on the procedures described in Willis (1996) and Sato and Takahashi (2008): Timed conversations were utilized as a task on selected topics of introducing each other, rude behaviors, an ideal life and happiness. At the beginning of class for each topic, learners were introduced to starter questions, model dialogues, useful words and phrases, and PPCSs. Then learners practiced talking with different partners during the class. The timings of topics and PPCSs are listed in Table 1 with PPCS labels for convenience.

Table 1. The timings of topics and instructed PPCSs

\begin{tabular}{|c|c|c|}
\hline $\begin{array}{l}\text { Learning } \\
\text { timing (topic) }\end{array}$ & PPCS & PPCS label \\
\hline April-May & $\begin{array}{l}\text { How are you feel- } \\
\text { ing? etc. }\end{array}$ & Greeting \\
\hline \multirow[t]{5}{*}{$\begin{array}{l}\text { (Introducing } \\
\text { each other) }\end{array}$} & $\begin{array}{l}\text { Nice talking with } \\
\text { you. etc. }\end{array}$ & $\begin{array}{l}\text { Leave-tak- } \\
\text { ing }\end{array}$ \\
\hline & Pardon me? & $\begin{array}{l}\text { Repetition } \\
\text { request } 1\end{array}$ \\
\hline & $\begin{array}{l}\text { That's interesting/ } \\
\text { surprising /etc. }\end{array}$ & Rejoinder 1 \\
\hline & $\begin{array}{l}\text { When/Where/ } \\
\text { Why/ How ...? }\end{array}$ & $\begin{array}{l}\text { Wh-/how } \\
\text { question }\end{array}$ \\
\hline & $\begin{array}{l}\text { Really? Oh, yeah? I } \\
\text { see. I know. OK. }\end{array}$ & Approving \\
\hline May-June & $\begin{array}{l}\text { repeating interloc- } \\
\text { utor's words }\end{array}$ & Shadowing \\
\hline $\begin{array}{l}\text { (Rude } \\
\text { behaviors) }\end{array}$ & Me too/Me neither. & $\begin{array}{l}\text { Sympathiz- } \\
\text { ing }\end{array}$ \\
\hline
\end{tabular}




\begin{tabular}{|c|c|c|}
\hline $\begin{array}{l}\text { Learning } \\
\text { timing (topic) }\end{array}$ & PPCS & PPCS label \\
\hline & $\begin{array}{l}\text { Would you say that } \\
\text { again? }\end{array}$ & $\begin{array}{l}\text { Repetition } \\
\text { request } 2\end{array}$ \\
\hline June-July & $\begin{array}{l}\text { What does... } \\
\text { mean? }\end{array}$ & $\begin{array}{l}\text { Meaning } \\
\text { check }\end{array}$ \\
\hline (An ideal life) & $\begin{array}{l}\text { Sounds exciting/ } \\
\text { necessary/etc. }\end{array}$ & Rejoinder 2 \\
\hline July-August & $\begin{array}{l}\text { Can you give me an } \\
\text { example? }\end{array}$ & $\begin{array}{l}\text { Example } \\
\text { request }\end{array}$ \\
\hline (Happiness) & $\begin{array}{l}\text { That's a difficult } \\
\text { question. }\end{array}$ & Rejoinder 3 \\
\hline
\end{tabular}

Specific grammar, which students often mistook, were extracted by the teacher from learners' conversations and introduced. Students tended to share common mistakes according to the assigned topic. Some examples are the conjugations of verbs, distinguishing infinitives, gerunds or verbs, differentiating verbs, adjectives or adverbs, and usages of tense. Students gradually understood a few specific mistakes.
After practicing once a week for a few weeks, learners recorded their conversations with a randomly assigned partner. This transcription and review was repeated for each of the different topics during the course.

\section{Subjects}

Subjects for the study were all Japanese female first-year junior college students studying nursing. Twenty-four of them agreed to participate in the study throughout the course in the first semester of 2012. Two of them were in their 30s and the others were 18 or 19 years old. They were at a novice level of proficiency. No student had taken the TOEICC or Eiken Tests.

\section{Data Collection}

Learners' PPCS use: The data was collected from learners' reports about their PPCS use. They underlined the PPCSs in their transcriptions and marked whether they had used them spontaneously without special effort or if they had tried to remember PPCSs and utilized them intentionally in their con-

Table 2. Criteria of learners' conversation

\begin{tabular}{|c|c|c|c|c|}
\hline \multicolumn{2}{|c|}{ Superior criterion } & Criterion & $\begin{array}{l}\text { Evalua- } \\
\text { tion }\end{array}$ & $\begin{array}{l}\text { Con- } \\
\text { version }\end{array}$ \\
\hline \multirow{5}{*}{ 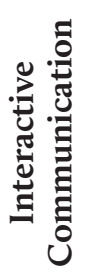 } & Initiating, & - Initiates and responds appropriately & \multirow{5}{*}{$\begin{array}{c}\mathrm{A}+ \\
\mathrm{A} \\
\mathrm{B} \\
\mathrm{C}\end{array}$} & \multirow{5}{*}{$\begin{array}{c}3 \\
2 \\
1 \\
0.5\end{array}$} \\
\hline & responding & & & \\
\hline & \multirow[t]{2}{*}{ Development } & \multirow{2}{*}{$\begin{array}{l}\text { - Maintains and develops the interaction and negotiates to- } \\
\text { wards an outcome with very little support }\end{array}$} & & \\
\hline & & & & \\
\hline & Use of PPCS & - Uses PPCS appropriately & & \\
\hline \multirow{7}{*}{ 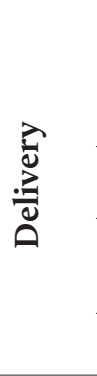 } & Intelligibility & - Pronunciation is intelligible & \multirow{7}{*}{$\begin{array}{c}\mathrm{A}+ \\
\mathrm{A} \\
\mathrm{B} \\
\mathrm{C}\end{array}$} & \multirow{7}{*}{$\begin{array}{c}3 \\
2 \\
1 \\
0.5\end{array}$} \\
\hline & & - Intonation is generally appropriate & & \\
\hline & & - Sentence and word stress is generally accurately placed & & \\
\hline & Volume & - Can be clearly heard & & \\
\hline & Fluency & - Produces extended stretches of language despite some hesita- & & \\
\hline & & tion & & \\
\hline & Pace & - Did not have extended pauses & & \\
\hline \multirow{4}{*}{ 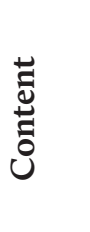 } & $\begin{array}{l}\text { Cohesiveness, } \\
\text { coherence }\end{array}$ & - Uses a range of cohesive devices & \multirow{3}{*}{ A+ } & 4 \\
\hline & \multirow{2}{*}{ Relevance } & \multirow{2}{*}{ - Contributions are relevant despite some repetition } & & 3 \\
\hline & & & & 2 \\
\hline & Depth, extent & - Can develop the topic and include support for the reasons & $\mathrm{C}$ & 1 \\
\hline
\end{tabular}

A+: Meets all of the criteria, A: Meets most of the criteria, B: Meets some of the criteria, C: Needs improvement 
versation. I counted how many times they utilized PPCSs and how many of them were intentional on the transcriptions by confirming their recorded material.

Learners' speaking ability: The recorded conversations were evaluated by the team teachers for the course: a native English teacher and me. Though we referred to the criteria of Sato and Takahashi (2008), the categorization was revised to divide broadly into interactive communication, delivery, and content from their fluency and content, accuracy, delivery, and strategies. Sato and Takahashi evaluated content with accuracy and definite CSs independently whereas we did not measure accuracy and included PPCSs in interactivity because we focused more on the interaction. We evaluated students as $\mathrm{A}+, \mathrm{A}, \mathrm{B}$, or $\mathrm{C}$, which were converted into numbers $3,2,1$ and 0.5 respectively in interactive communication and delivery and from 4 to 1 for content (see Table 2).

Learners' perceptions: Learners reviewed their conversation after each audio recording using a 4-point Likert-scale (4 = Yes, 3 = Maybe yes, 2 = Maybe no, and $1=\mathrm{No}$ ) focusing on whether or not they enjoyed the conversation, understood their partners' English, tried to communicate with their partners, could say what they wanted or whether it felt easy to speak in class. These were labeled enjoyment, understanding, communicating, facility and easiness for convenience. They also gave written feedback in Japanese to complement the questionnaire. Learners might have various perceptions which could not be obtained through the questionnaire and they might have different feelings than they could express in the Likert-scale answers to the questionnaire. The written comments provided information about these perceptions.

\section{Analysis with Mixed Methods}

According to Dörnyei (2007), quantitative and qualitative methods are not necessarily mutually exclusive, so the author combined them in order to gain from both. RQ1 was analyzed using quantitative data, because the frequency of PPCS use was counted while listening to the recordings. RQ2 and RQ3 were analyzed using both quantitative and qualitative data because quantitative data were necessary to examine the correlations, while open-ended comments were expected to elucidate the participants' ideas and feelings. The learners' written comments could be categorized by keywords, which were converted to numerical values.

\section{Results}

Learners' PPCS use: All PPCS occurrences of each student were totaled (see Table 3). The utilizations of greeting and leave-taking were almost constant from the first topic to the last topic. Rejoinder 1 , Wh-/how question and approving, which were introduced in the first topic, were used the most in the recordings for the topic. Moreover, shadowing and sympathizing, introduced for the second topic, were used the most in the recording for that topic. Likewise, meaning check, rejoinder 2, example request and rejoinder 3 were employed when first instructed, though their frequencies of use were not high. Different from these PPCSs, repetition requests 1 and 2 did not show any clear tendency (see Table 3).

Most of the percentages of intentionally used PPCSs to the total of each PPCS decreased as they continued their conversations (see Table 4). The exceptions were Wh-/how question and shadowing, which kept high ratios until the last topic and repetition request 1 , which was always used without any effort. Example request and rejoinder 3 were

Table 3. The frequency of PPCS utilizations in each recording

\begin{tabular}{|c|c|c|c|c|c|c|c|c|c|c|c|c|c|}
\hline & 菢 & 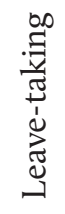 & 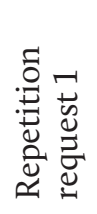 & 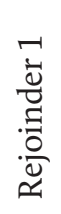 & 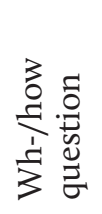 & 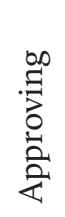 & 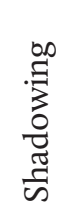 & 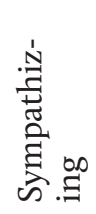 & 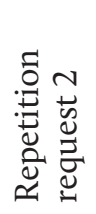 & 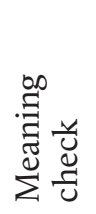 & 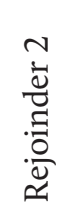 & 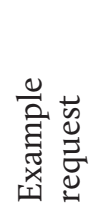 & 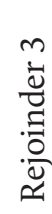 \\
\hline April 26 & 24 & 23 & 2 & 69 & 64 & 33 & 0 & 0 & 0 & 0 & 0 & 0 & 0 \\
\hline May 31 & 24 & 17 & 6 & 20 & 27 & 29 & 44 & 35 & 0 & 0 & 0 & 0 & 0 \\
\hline June 21 & 23 & 22 & 3 & 15 & 31 & 18 & 36 & 8 & 0 & 5 & 30 & 0 & 0 \\
\hline August 2 & 24 & 24 & 3 & 51 & 21 & 15 & 14 & 5 & 0 & 3 & 1 & 2 & 3 \\
\hline
\end{tabular}

$N=24$, Figures show total PPCS use of 24 students in each recording (number of times) 
introduced for the last topic and the process of their acquisition and use could not be adequately examined.

Learners' speaking ability: The average scores of the four recorded conversations were 8.83, 7.42, 8.78 and $9.25(S D=.800, N=24)$ respectively.

Learners' perceptions: Learners' perceptions after the recordings and evaluation by the teachers showed similar fluctuations. That is, they began rather positively in the first topic but decreased in the second topic. They increased for the third topic, however, went down again, despite the improved conversation evaluation by the teachers (see Figure 1 ) and Table 5 shows their means and standard deviations.

The results of learners' impressions written in Japanese could be mostly classified into three groups: enjoyable, difficult and stressful. A student added the reason: "I am familiar with 'This is ... or 'That's ...' since my high school days but not with 'Sounds ...' Another student admitted that "'Would you say that again?' or 'Can you give me an example?' is too long and so it was difficult to say without using notes."

Table 4. Intentionally utilized PPCS in each recording

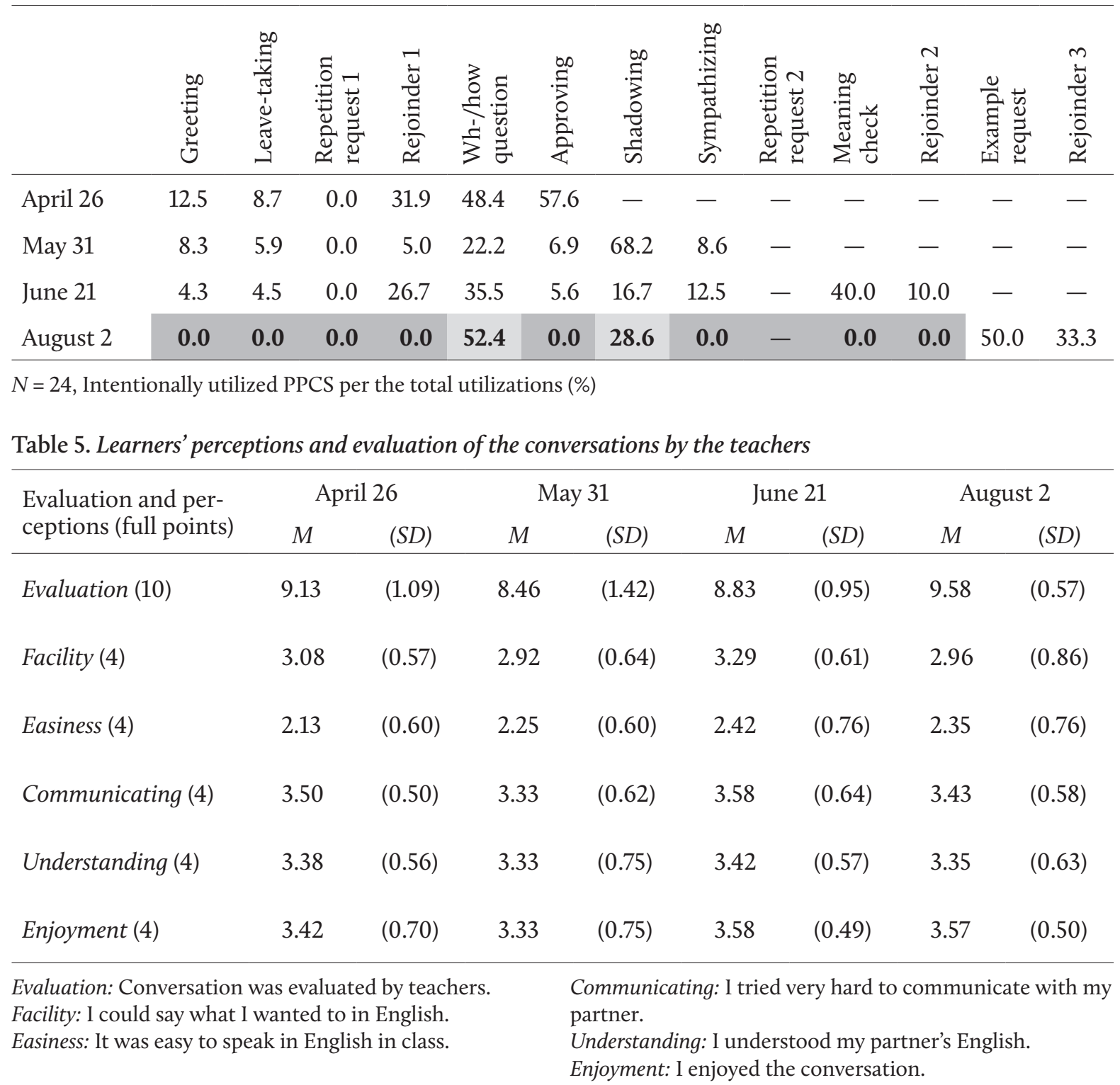


Correlations (Pearson's product moment correlation coefficient): Significant correlations were shown between the utilization of Wh-/how question and rejoinder 1 (That's ...) (r (22) = .597, p < .01). There was also a significant correlation between evaluations of recorded conversations and the frequent use of rejoinder $1(\mathrm{r}(22)=.248, \mathrm{p}<.05)$. Other significant correlations were seen between learners' perceptions and the numbers of PPCS use: facility and total PPCS use $(\mathrm{r}(22)=.228, \mathrm{p}<.05)$; easiness and repetition request $1(\mathrm{r}(22)=.674, \mathrm{p}<.05)$; and enjoyment and total PPCS use $(\mathrm{r}(22)=.248, \mathrm{p}<.05)$.

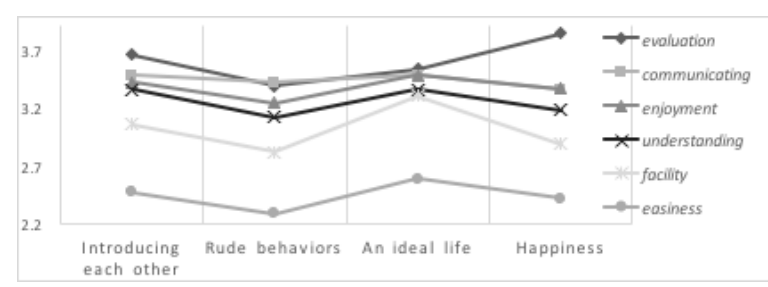

Evaluation: Evaluations by teachers were converted into the maximum of 4 .

Others are numbered as Yes: 4, Maybe yes: 3, Maybe no: 2, No: $1 . \quad N=24$

Figure 1. Learners' perceptions and evaluation of the conversations by the teachers.

\section{Discussion}

The results above show that students' interest in PPCSs shifted from previously learned ones to new ones. Learners tried to concentrate on what had been taught immediately before their conversation. Although they did not employ the previous PPCSs when they had not been conversant with them, they tended to adhere to the PPCSs they had learned prior to the newly introduced and simpler PPCSs and easily substituted the previously learned PPCSs. For example, they preferred rejoinder 1 (That's ...) to the subsequently learned rejoinder 2 (Sounds ...), and repetition request 1 (Pardon me?) to repetition request 2 (Would you say that again?). Students had a tendency to depend on syntactically simpler and previously-learned PPCSs if they could be manipulated with more limited expressions. While a variety of expressions are necessary to improve their English, the learners in this study need confidence that they can say what they want to in English and it is easy to speak English in class because their perceptions were not high. When they feel they can say what they want to easily, perhaps they will be ready to use a variety of more complicated and sophisticated expressions.

The low but significant correlation coefficient between the utilization of rejoinder 1 (That's ...) and evaluation of the speaking ability by the teachers should not be ignored because this was the most frequently utilized PPCSs. Moreover, students' intentional use of the PPCSs is low when their evaluation of the conversation is high.

In the majority of PPCS use, the more often students used certain PPCSs, the less intentionally they utilized them. Rejoinder 1 (That's ...) is a typical PPCS of this characteristic while wh-/how question was exceptional and needed attention even after many trials. Nevertheless, there was a significantly high correlation between them.

Moreover, the strong significant correlation between easiness and repetition request 1 (Pardon me?) and significant but weak correlation between facility and total of all PPCS use are noteworthy because these perceptions of learners are the two lowest of the five items. Learners' action of asking back without overlooking what learners could not understand might have led to positive perception of easiness and by utilizing PPCS more, they might have felt that they could say what they wanted to.

\section{Conclusion}

I would like to conclude by referring to the research questions. What PPCSs do low-proficiency Japanese college students use in prompted TBLT activities after PPCS instruction? The novice learners used simple and newly-learned familiar PPCSs which could be utilized for diverse expressions across multiple topics. However, it would be productive to encourage them to use more of a variety of underutilized PPCSs. Moreover, even in rejoinder 1 , which was utilized most frequently, few of the learners used diverse adjectives in their performances. They represented their feelings by repeating "That's nice" or "That's good." Therefore, emphasis on a broader variety of adjectives would more fully exploit this PPCS potential. With better understanding and a wider variety of adjectives at their disposal, these PPCSs could make greater contributions to the success of their discourse.

The second research question, which is about PPCS utilization and learners' communication abilities, has a less definitive answer. The most frequently used rejoinder 1 (That's ...), which was taught first, is relevant to the student speaking ability evaluated by teachers. More data could affirm the effectiveness of PPCS instruction because this study is based on only 24 students for one semester. However, the results are encouraging and I look forward to clarifying or reaffirming my current understanding and improving students' learning of a second language through application of TBLT in light of the significance of relevant PPCS use. 
For the third research question, correlations between certain PPCS as well as between learners' positive perceptions and some PPCS uses are noteworthy. The significantly high correlation coefficient between rejoinder 1 (That's ...) and wh/how questions, whose PPCS usages and intentionality were distinctive, deserves special mention. Reasons for the correlation were not investigated; however, this correlation may provide a clue to improve PPCS which required more practice. Furthermore, correlations involving perceptions of easiness and facility, which are meaningful cognition for learning $\mathrm{L} 2$, are an incentive, especially for novice learners to accumulate their experience in the target language using PPCSs.

Thirteen PPCSs were examined in this research. It is natural that they have diverse possibilities of utilization in authentic conversation tasks. Based on this research, some of the distinctive PPCS instruction needs to be further investigated to derive more qualitative data on PPCS utilizations from more learners.

\section{References}

Brown, H. D. (2007). Teaching by principles: An interactive approach to language pedagogy (3rd ed.). New York: Pearson Education.

Canale, M. (1983). From communicative competence to communicative language pedagogy. In J. Richards and R. Schmidt (Eds.) Language and communication. London, UK: Longman.

Canale, M., \& Swain, M. (1980). Theoretical bases of communicative approaches to second language teaching and testing. Applied Linguistics, 1, 1-47.

Corder, S. P. (1981). Error analysis and interlanguage. Oxford, UK: Oxford University Press.

Dörnyei, Z. (1995). On the teachability of communication strategies. TESOL Quarterly, 29, 55-85.

Dörnyei, Z. (2007). Research methods in applied linguistics: Quantitative, qualitative, and mixed methodologies. Oxford, UK: Oxford University Press.

Ellis, R. 2008. The study of second language acquisition. Oxford, UK: Oxford University Press.

Færch, C., \& Kasper, G. (1983a). Plans and strategies in foreign language communication. In C. Færch \& G. Kasper (Eds.), Strategies in interlanguage communication (pp. 20-60). Essex, UK: Longman.

Færch, C. \& Kasper, G. (1983b). On identifying communication strategies in interlanguage production. In C. Færch \& Kasper (Eds.), Strategies in interlanguage communication (pp. 210-238). Essex: Longman.

Kellerman, E. (1991). Compensatory strategies in second language research: A critique, a revision, and some (non-)implications for the classroom. In R. Phillipson, E. Kellerman, L. Selinker, M. Sharwood Smith, \& M. Swain (Eds.), Foreign/second language pedagogy research (pp. 142-61). Clevendon, UK: Multilingual Matters.
Lightbown, P. M., \& Spada, N. (2006). How languages are learned (3rd ed.). New York: Oxford University Press.

Nakatani, Y. (2005). The effects of awareness-raising training on oral communication strategy use. The Modern Language Journal. 89(1), 76-91.

Nakatani, Y. (2010). Identifying strategies that facilitate EFL learners' oral communication: A classroom study using multiple data collection procedures. The Modern Language Journal, 94(1), 116-136.

Nakatani, Y., \& Goh. C. (2007). A review of oral communication strategies: focus on interactionist and psycholinguistic perspectives. In A. D. Cohen \& M. Ernesto, (Eds.), Language learner strategies (pp. 207-227). New York: Oxford University Press.

Sato, K., \& Takahashi, K. (2008). Curriculum revitalization in a Japanese high school: Teacher-teacher and teacher-university collaboration. D. Hayes \& J. Sharkey (Eds.), Revitalizing a curriculum for school-age learners (pp. 205 - 237). Alexandria, VA: TESOL, Inc.

Savignon, S. J. (1972). Communicative competence: An experiment in foreign-language teaching. Philadelphia, PA: The Center for Curriculum Development.

Tarone, E. (1981). Some thought on the notion of 'communication strategy.' In C. Faerch \& G. Kasper (Eds.), Strategies in interlanguage communication (pp. 61-74). Essex, UK: Longman.

Tarone, E. (1984). Teaching strategic competence in the foreign-language classroom. In S. J. Savignon \& M. S. Berns (Eds.), Initiatives in communicative language teaching (pp. 127 - 136). Boston, MA: Addison-Wesley.

Willis, J. (1996). A framework for task-based learning. Essex, England: Pearson Education Limited.

\section{Yoshiko Kozawa is a reg-} istered nurse who, after teaching English for six years to nursing students, wanted not only to understand the medical knowledge they should acquire, but also to experience their challenging conditions. She is currently teaching English to nursing students at Suzuka University of Medical

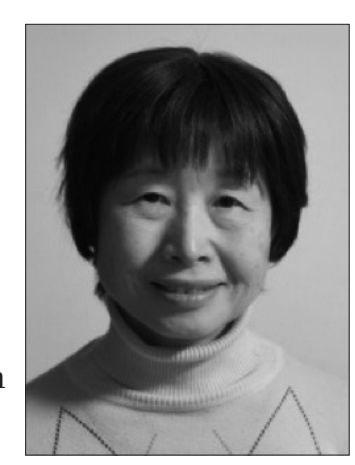
Science and at Aichi Kiwami College of Nursing. She has been applying English for Specific Purposes (ESP) in Task-Based Language Teaching (TBLT) to motivate her students. In particular, her research interests include improving nursing students' communication skills in English in a more comfortable approach using TBLT communication strategies. 